\title{
PERCENTAGE OF TOTAL PLANT MONOCOTS AND DICOTS IN SERDANG MENANG VILLAGE, SIRAH PULAU PADANG SUB- DISTRICT, OGAN KOMERING ILIR DISTRICT
}

\author{
Ari Sugiarto \\ Department of Biology, Faculty of Mathematics and Natural Sciences, Sriwijaya University \\ Email: sugiartoari13@gmail.com
}

\begin{abstract}
Abtrack
Dicotyledonous plant is a plant that has the characteristic that transporter tissue files are in a loop, while monocot plants are plants that have the characteristic that the tissue transporter beam spread. Morphological differences between plants dicots and monocots can be seen from the roots, stems, leaves and flowers. Dicotyledonous plants rooted riding, rod cambium, pinnate leaves and flower jewelry section consisting of 2, 4,5 or multiples thereof. Monocot fibrous roots, stems not cambium, leaves curved, parallel, flower jewelry section consists of 3 or multiples thereof. The research was conducted on Sunday, May 15, 2016, in the Serdang Menang village, Sirah Pulau Padang, Ogan Komering Ilir. Tools and materials used are stationery and notepads. Number of dicotyledonous plants located in the village of Serdang Menang totaling 94 species, while the monocot plants totaling 30 species were found. Total comparison 75, $8 \%$ (plants dikotil) and 24, 2\% (plants monocots).
\end{abstract}

Keywords: Dicots and Monocots

\section{Introduction}

Plant seeds are now closed there is still covering 170,000 \pm types, divided into more than 10,000 genera, all of which are covered in more than 300 tribes. Seed plants covered are usually divided into two classes, each of which is named according to the number of leaves the institution (cotyledo) which has members, namely the class of monocots or seed plants split (Dicotyledoneae or Dicotylae) whose members - members have seeds with an institution that has 2 leaves the institution. Class monocot plants or plant a single seed (Monocotyledoneae or Monocotylae) whose members have seeds with an institution that has only one leaves the institution (Tjitrosoepomo, 2010).

Dicotyledonous plant is a plant that has the characteristic that transporter tissue files are in a loop, while monocot plants are plants that have the characteristic that the tissue transporter beam spread. Morphological differences between plants dicots and monocots can be seen from the roots, stems, leaves and flowers.
Dicotyledonous plants rooted riding, rod cambium, pinnate leaves and flower jewelry section consisting of 2, 4, 5 or multiples thereof. Monocot fibrous roots, stems not cambium, pertulangan leaves curved, parallel, flower jewelry section consists of 3 or multiples thereof.

According Tjitrosoepomo (2010), the morphological features of plants dikotil that have agencies with two leaves the institution (grain split) and the roots and shoots institution that has no special protective, roots institutions grow steadily into the basic root (taproot) branching and forming a taproot system, cone-shaped stem length, leaf sitting tau tersebara usually rocky, single or compound leaves, and flowers are di-, tetra-, or pentamer.

The anatomy of plants dikotil has circharacteristic roots and stems have the network available cambium and beam transporter (xylem and phloem) are arranged in a circle.

Monocotyledoneae class over a number of nations and tribes plants that citizens deemed to have a high degree of 
phylogenetic development. Plant species belonging to this class can be recognized by the following characteristics. Morphological characteristics such as herb, shrubs, or trees that have the root system of vines, woody stems or not, usually do not or are not many branches, books or sections most apparent, leaves most single rare compound, reinforced parallel or curved.

In terms of anatomy citizens Monocotyledoneae discrete root has a structure consisting of networks of primary course with a central cylinder belonging aktinostele and endodermis that in the cross section can clearly be differentiated cells that thicken and are not able to pass water and food substances dissolved in it with cells that normally deal with one file timber vessels whose walls are not thickened and is the influx of water from the outside of the root into the files pumbuluh transporter (Tjitrosoepomo, 2010).

The leaves are pinnate reinforced (penninervis). This leaves a mother has bone that runs from the base to the tip and is a continuation of the petiole. From the mother's bones laterally out the bones of the branches, so that the order reminiscent of the arrangement of fins in fish, so called reinforced pinnate. Leaves with such arrangement is generally we find the seed plants sides (Dicotyledoneae), eg mango leaves (Tjitrosoepomo, 2012).

Epidermal tissue dicotyledonous plant consists of a layer of cells that is compact, has no space between cells. The epidermis at the stem dicotyledonous has cuticle and cell wall berkutin contained in the outermost part. Him there stomata and various trichomes. The function of the epidermis to protect the underlying tissue. On the stem secondary growth, the epidermal layer is replaced by a layer of cork which is formed from the cork cambium. A layer of cork in plants is useful to increase the power protection stems and reduce water evaporation (Pranita et al., 2010).
Total leaves the institution in seeds is one of the characteristics that are important in the classification of seed plants hold. Plants whose seeds have a shape like a shield and a duty to suck food from pistil institutions, and called skutelum. Plants which have only one leaves the institution called the plant a single seed (Monocotyledoneae), because seed looked intact or single.

Plants whose seeds have two leaves agencies with agencies. These seeds visibly consists of two parts or two pieces, so that plants with seeds having the character of such a class of another who dianamakan seed plants split or Dicotyledoneae (Tjitrosoepomo, 2012).

The Serdang Menang village is situated in the region wetland, there is no research that says the percentage of plants dicots and monocots plants in this region. Therefore, to investigate the percentage of the number of plants dicots and monocots plants in Serdang Menang vilage District of Sirah Pulau Padang Ogan Ogan Ilir.

\section{Research methods}

The research was conducted on Sunday, May 15, 2016, in Serdang Menang village, Sirah Pulau Padang, Ogan Komering Ilir. Tools and materials used are stationery and notepads. This research was conducted by means of plant records contained in Serdang Menang vilage, District Sirah Pulau Padang, Ogan Ogan Ilir and divide it into classes of plants dicots or monocots.

\section{Region Serdang Menang village (Imagery by Google Map)}

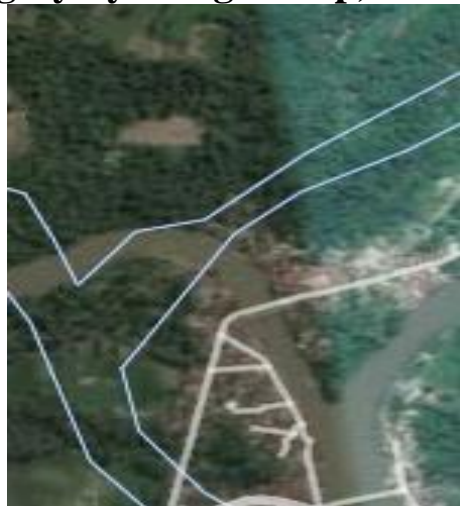




\section{Results and Discussion \\ Results}

Based on the research that has been conducted showed that:

Table number of plants dicots and monocots

\begin{tabular}{|c|c|c|}
\hline $\begin{array}{c}\text { The } \\
\text { percentage of } \\
\text { the number of } \\
\text { plants dicots } \\
\text { and monocots }\end{array}$ & Dikots & Monocots \\
\hline Total species & 94 & 30 \\
\hline
\end{tabular}

From the research conducted found dicotyledonous plant species totaling 94 species and 30 species of plants monocots numbered. This table shows the number of plant species dikotil outnumber monocot plants.

\section{Comparison charts plants dikots and monocots}

Comparison of plants dikots and monocots

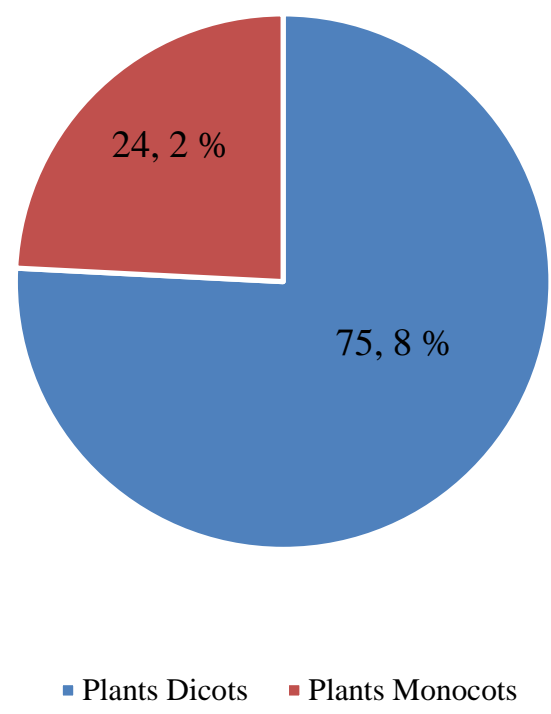

\section{Discussion}

Based Observation of which have to be got that, the number of plants dikotil obtained amounted to 94 species and number of plants monocots found amounted to 30 species. Comparison of plants dicots and monocots is $75,8 \%$ of plants dicotyledonous and $24,2 \%$ of plants monocots.

Desa Serdang Win located in swampy areas. This shows that the number of plants dikotil swamp ecosystem more than the number of plants monocots. Dicotyledonous plant is classified as plants that have a long life while monocot plants cendrum short lifespan.

Most of the plants dikotil found a tall plant whereas monocot plants are found mostly in the form of grass.

\section{Conclusion}

Based on the research that was done it was concluded that:

1. The number of plant species in the Village dicots and monocots Serdang Menang District of Sirah Pulau Padang Ogan Ogan Ilir, totaling 124 species, 94 species dikots and 30 species monocot plants.

2. Vilage Serdang Menang Situated in a swamp area

3. Most of the plants dikotil found a tall plant and found most of monocot plants are grasses.

\section{Reference}

Pranita, R., Y. R. Fitri, T. Asneti, Juwilda, E. F. Zeba. 2010. Epidermis Pada Tumbuhan. Makalah. Universitas Sriwijaya: Inderalayah.

Tjitrosoepomo, G. 2012. Morfologi Tumbuhan. Gadjha Mada University Press: Yogyakarta. x + $268 \mathrm{hlm}$.

Tjitrosoepomo, G. 2010. Taksonomi Tumbuhan (Spermatophyta). Gadjha Mada University Press: Yogyakarta. $\mathrm{x}+477 \mathrm{hlm}$. 